\title{
EVALUATION OF STABILISED-EARTH (TEK) BLOCK FOR HOUSING PROVISION AND CONSTRUCTION IN GHANA
}

\author{
R. A. Oppong ${ }^{1}$ and E. Badu ${ }^{2}$ \\ ${ }^{1}$ School of Architecture, University of Liverpool, Merseyside, Liverpool,L69 7ZN, UK \\ ${ }^{2}$ Department of Building Technology, KNUST, Kumasi, Ghana
}

\begin{abstract}
Lack of patronage of locally developed building materials has resulted in huge housing deficit and expensive housing construction in Ghana. Housing appears not to be serving as social good in Ghana. The new housing environments in Ghana are characterized by hitherto lesser known and exotic building materials. Through mapping of case study areas and ethno-narratology (narrative) approaches within the qualitative methodological paradigm, selected urban and rural communities were surveyed. Users' perception of their houses and housing environments built of TEK blocks are presented in this paper. This paper speculates that TEK blocks as earth based building material can contribute to the alleviation of housing problems if there are conscious efforts of nationwide adoption of coordinated programmes and efforts.
\end{abstract}

Keywords: TEK (SEB) blocks, ethno-narratology, housing, materials, Ghana

\section{INTRODUCTION}

The provision of adequate housing in decent human settlement is essential to satisfy the physical and biological as well as social requirements of man, in order to improve his quality of life (Kronenburg, 2001). However, despite upward trends in housing production over the years, generally, the increases are not enough to offset the accumulated deficits, and also to meet the needs of the increase in population in urban Ghana (Andersen et al., 2006). With the failure of the nation taking decisive and sustainable action on housing materials to enable production of housing (Badu and Owusu -Manu, 2011), it comes as no surprise that housing shortage has hit government officials, leading to political upheaval. From time immemorial, earth and other natural building materials have recognisably been used as cheap materials for the construction of houses based on human experiences (Hadjri et al., 2007). Notably, one of the most famous landmarks in Africa dating back to the 13th century and designated as World Heritage Site by UNESCO in 


\section{Oppong and Badu}

1988, The Great Mosque of Djenné in Mali is the largest mud brick building in the world and is considered by many as the greatest architectural achievement (Bourgeois, 1987). Kostof (1995) asserts that the first permanent settlement in Jericho (Israel) built about 7500 B.C. had solid domed houses of mud-brick. However, the sensitivity of earth based buildings to moisture with the resultant effects of cracks on drying, erosion and structural collapse, have been the major setbacks of earth as building materials (Zami and Lee, 2011).

To overcome that, stabilising agents such as fibrous materials, lime and cement were introduced to mix with right earth type to improve their strength and durability to meet the performance requirements for safety, thermal and acoustic comfort, ease of use, adaptability and cost (Jalali and Pimenta, 1999). This encouraged the introduction of stabilised-earth blocks (SEBs) in Ghana by the defunct Department of Housing and Planning Research (DHPR) of the Kwame Nkrumah University of Science and Technology (KNUST) in Kumasi to test ways of reducing cost of housing development and to increase the housing stock for lower income groups in Ghana (DHPR, 1971). The first SEB produced at KNUST almost four decades ago was branded as TEK- Block (Okie, 1971). The TEK block found favour of acceptability in Ghana at its inception stages. It came to mean virtually as good substitute of a block pressed from a sand-cement mixture, in the attempts to reduce over dependence on imported building materials (DHPR, 1971). The TEK block was used in the 103 houses under the operational pilot housing scheme in Community 8, Tema (DHPR, 1971). In 1974, as a design policy for the resettlement housing at New Nsutam near Bunso in the Eastern Region of Ghana, stabilised-earth floors were used to provide low cost but high quality houses (Abloh et al., 1974)

Numerous researches indicate that Ghana, similar to several African countries such as Zambia, Kenya, Uganda, Nigeria, Tanzania and Southern Africa, are experiencing new forms of housing construction due to massive influx of people from rural areas, resulting in high demand for housing (Hadjri et al., 2007; Owusu, 2001). Notwithstanding, the TEK-Blocks application in housing construction in Ghana has not been encouraging if not completely forgotten when all earlier researches approved the material's suitability and therefore developed various technologies for its use in building construction. However, TEK-Blocks' durability and perceived social image are far from satisfactory (Jalali and Pimenta, 1999). Zami and Lee (2011) asserted that stabilised-earth block is disadvantaged by the incorrect perception that it is not a "permanent" building material; it is strongly associated with traditional unstabilised soil construction in the minds of many due to the small quantity of cement as stabilising agent.

Dinye and King (1984) asserted that the acquisition of cement was obvious problem as well as the manual equipment for mass production of stabilised-earth blocks was found to be inadequate and often poorly designed and its purchasers appeared generally unable to distinguish good design from bad. Gbeckor-Kove (1988) acknowledged that the TEK block tested and recommended by the DHPR proved successful in many cases except where the mixing of sand and cement was badly done, leaving patchy sections of the block unstabilised. Logistical constraints, regarding, for example, the processes of acquiring sites with large volumes of lateritic soil and transportation, technical and skilled workers to operate the Tek-block machine militated against stabilised-earth block as building material in Ghana (Dinye and King, 1984). Another setback for stabilised-earth blocks has been the absence of quality control procedures and in particular of testing equipment to monitor quality (Zami and Lee, 2011). It is worth noting that it is difficult to determine the suitability of stabilised-earth blocks even with particle distribution tests and other laboratory tests (Sperling, 1962). The nature of the building materials, especially sandcrete or sand -cement blocks and housing construction, has 
Evaluation of stabilized-earth (TEK) block... 106

been sufficiently treated elsewhere by Yeboah (2003), Ofori (1985) and others but their conclusions are largely characterised by users' poor attitudes towards earth building materials on one hand, and lack of technical knowledge as well as building codes and regulations on the other. The apparent lack of attempts to address those problems has been compounded by taste of modernization for sand-cement or concrete housing construction technology (Afrane and Asamoah, 2011). Cement based building materials are preferred more readily to earth based building materials. It is therefore for the foregoing that this study was undertaken to evaluate the TEK-Blocks as construction material in order to foster an improved understanding of the factors which have rendered the use of TEK -Block as ineffective for house construction in Ghana. This paper, qualitatively evaluates TEK block as earth based building material from users' perspective to ascertain its viability as a credible material for house construction in Ghana

\section{BRIEF DEVELOPMENT ACCOUNT OF TEK BLOCK}

Following on from the preceding section, this paper turns to the roots of the TEK blocks. That is important, because the genesis of TEK block is not mentioned in the seminal publications by Okie (1971). In the early 1968, The Faculty of Architecture - KNUST, which became Faculty of Environmental and Development Studies and now College of Architecture and Planning, identified the need to have a locally manufactured machine for block moulding to help house construction industry in Ghana on a more sustainable scale. The Faculty of Architecture subsequently requested the Department of Mechanical Engineering-KNUST for an engineering solution to a two-fold problem of:

i. continuously mixing of lumpy laterite, dug straight from the ground and allowed to partially dry and then mixed with 3 to $6 \%$ cement to form a fine grained monofenious mixture and;

ii. to compress the loose laterite mixture into 6 "x8" 12 " blocks with the entire process of loading of the mixture, compression, and block ejection done mechanically (OseiAsibey, 1987).

\section{Approach to actualisation}

To actualise the above, several discussions, brainstorming and demonstration sessions were held between the staff of the Mechanical Engineering Department and the Faculty of Architecture on the request. When finally, the Mechanical Engineering Department was convinced that the project was feasible and worth pursing, the project was assigned to Mr. F. Dove - a final year Mechanical Engineering student (Osei-Asibey, 1987). Under the competent professional supervision of Dr. A. Abrobah-Cudjoe, Mr. F. Dove produced the design of the TEK Block Press under the Project Title: Design of a Mechanical Block Making Machine in 1968. The good sense of co-operation between the Faculty of Architecture and the Mechanical Engineering Department resulted in the design and manufacturing of TEK Block Press for the production of TEK-Blocks (OseiAsibey, 1987).

\section{The science of TEK-Block: A snapshot}

The practical index quality of TEK-Block is the improved compressive strength to enhance other desirable characteristics like dimensional stability and durability (Sperling, 1962). In 1988, the Department of Housing and Planning Research (DHPR) consulted the Building and Road Research Institute (BRRI) in Kumasi to carry tests on lateritic earth TEK block (DHPR, 1971). A memorandum from the BRRI to the DHPR indicated that earth of medium plasticity, with average liquid limit of 45 , plastic limit of 2.3.0 and plasticity index of 22.0 is suitable for house construction blocks. The report further asserted that, for Atterbergs limits, the particle size distribution of earth should be suitable for cement stabilization (DHPR, 1971). Further research estimated that strength property of 5$20 \%$ of the compressive strength is good for TEK block. Working on the Kenper marl soil did show that for cement stabilised specimens, prepared at British Standards (BS) optimum 
moisture content, increase in compressive strength was observed as the compaction moisture content was increased to the B.S optimum, the dry density remains constant (Dunn and Obi, 1969).

\section{MATERIALS AND METHODS}

To gain a deeper understanding and appreciation of TEK Block as earth based building material, extensive use was made of the case study approach or 'ethno-narratology' (a combination of ethnographies and narratives (see; for example, Wellington, 2011; Zaretsky, 2011; Hadjri, 2010). By ethno-narratology, this study lays particular emphasis on the immersion of researchers in the cultural context of the case study areas in an attempt to ascertain how the users of TEK blocks perceive and interpret the usefulness of the material. It enables this study to rely on "participant observation" as primary mode of data collection (Zaretsky, 2011; Groat and Wang, 2002). Under this approach, purposively selected rural and urban communities were mapped out for holistic exploration of locations using context-rich detail; and semistructured questionnaire. The study focused on single or smaller population within the case study areas (Table 1). Data analysis was mainly inductive and this paper reports on key themes from the field data and sections of interviews to ground the themes as demonstrative quotations from individual respondents through the Delphi technique. The Delphi technique is flexible and specifics of the method features vary by application (Davies et al., 2011); it can be used when there is incomplete knowledge of a problem or phenomena and can be applied to problems that do not lend themselves to precise analytical techniques (Zami and Lee, 2011).

The exploratory nature of Delphi technique could render the subjective judgments of individuals beneficial on a collective basis to focusing on problem at hand (Zami and Lee, 2011). The Delphi technique was used to triangulate and ground perceptions from stabilized-earth block house owners expressed in the semistructured questionnaire survey of thirty-two respondents from carefully selected expert respondents (Nworie, 2011). Twenty-two (22) TEK block house owners and ten (10) households as well as two (2) public officials were involved in formal interviews; and, two (2) focus group discussions (Group 1: $\mathrm{N}=5$ and Group 2: $\mathrm{N}=7$ ) were also held with general users. Acceptance, durability/performance, popularity, affordability levels and design and construction as well as maintenance issues of the material were the main themes for discussion in a form of "constructive dialogue" (Seemann, 2011); the research participants in group meetings explored the issues affecting stabilised-earth blocks. Interviews were structured so that participants described their perceptions and experiences from early days as owners or occupants through to present time. An obvious advantage of this is that it enables researchers to assess the impacts from the respondents' perception instead of their own tainted perceptions.

A substantial portion of the information used in this paper was, however, obtained from archival material and group discussions in each of the study areas. The survey was carried out over a six-year period with intermittent inputs from April 2005 to mid-2010. Due to poor records keeping and lack of building locations directory in Ghana, TEK block buildings were searched and mapped out between April 2005 and June 2007. Field survey and interviews were carried out between June 2008 and mid2010. The study areas were selected primarily based on their uniqueness as geographical locations of TEK block buildings. It is to the last statement that the next section offers brief description nuanced with historical accounts and justification of the case study areas (Fig 1).

\section{Portrait of study areas}

The following areas, all in Ghana were purposively sampled for this research. The areas included KNUST, Ayeduase, Ankaase and Nkenkaasu in the Ashanti Region; Bunso in the Eastern Region; and Tema in the Greater Accra Region (Fig 1). 
Table 1: Sample of locations of TEK Blocks in Ghana

\begin{tabular}{ccccccccc}
\hline Building type & KNUST & Ayeduase & Ankaase & Nkenkaasu & Bunso & Tema & Total & \% \\
\hline Residential & 3 & 1 & 4 & 11 & 0 & 62 & 81 & 91 \\
Educational & 3 & 1 & 0 & 0 & 0 & 0 & 4 & 4.5 \\
Commercial & 0 & 0 & 0 & 0 & 0 & 0 & 0 & 0 \\
$\begin{array}{c}\text { Civic/Cultural/ } \\
\text { Religious }\end{array}$ & 0 & 1 & 0 & 0 & 1 & 0 & 2 & 2.25 \\
Industrial & 1 & 0 & 0 & 0 & 1 & 0 & 2 & 2.25 \\
TOTAL & $\mathbf{7}$ & $\mathbf{3}$ & $\mathbf{4}$ & $\mathbf{1 1}$ & $\mathbf{2}$ & $\mathbf{6 2}$ & $\mathbf{8 9}$ & $\mathbf{1 0 0}$ \\
\hline
\end{tabular}

Source: Author's Field Survey, 2006

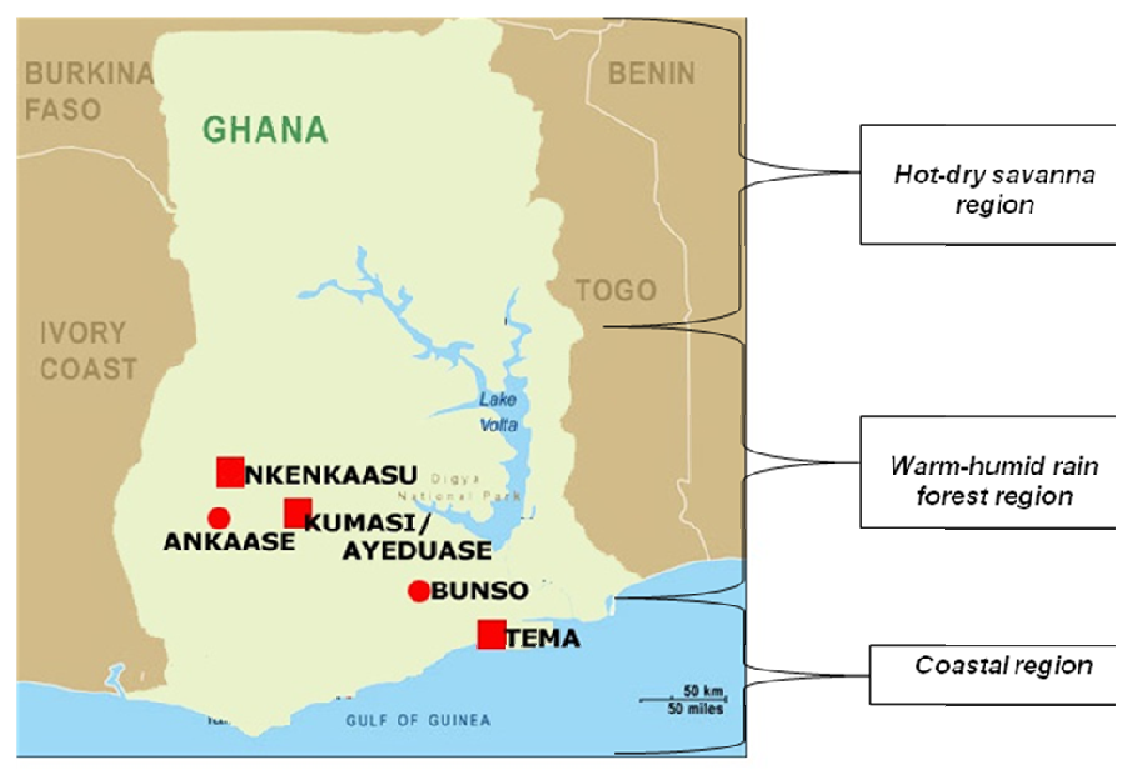

\section{LEGEND}

AREAS OF HIGH CONCENTRATION OF TEK BLOCK BUILDINGS

- AREAS OF MINIMAL CONCENTRATION OF TEK BLOCK BUILDINGS

Fig. 1: Map of Ghana showing study areas and TEK blocks buildings locations Source: Author's Field Survey, 2008 


\section{Kumasi/Ayeduase}

Kumasi, the Ashanti Regional capital was selected due to the fact that the Department of Housing and Planning Research (DHPR) which happened to be the production centre of the TEK-Block, had built a number of experimental buildings in and around Kumasi. The DHPR had to its credit, a number of experimental buildings including office, workshop, residential and students hall of residence "Shaba"
(Fig. 2 and 3).

Ayeduase is sub-urban community and lies in close proximity to the Eastern part of KNUST. The effects of the activities of the University easily sprawled into the surrounding communities. The classroom buildings for the Ayeduase Primary School were built with the TEK-Block. The Ayeduase Chief's Palace was partially built with TEK-Blocks.

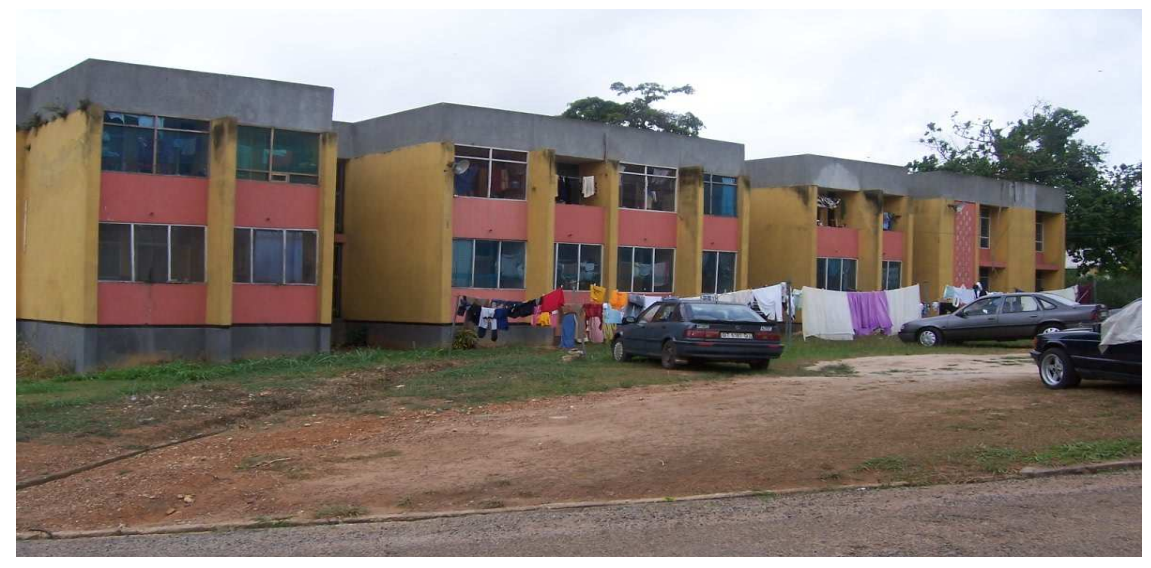

Fig. 2: The 2-storey Students Hostel Development (popularly known as "Shaba Province" )on KNUST campus built in 1970 (Source: Authors' Field Survey, 2008).

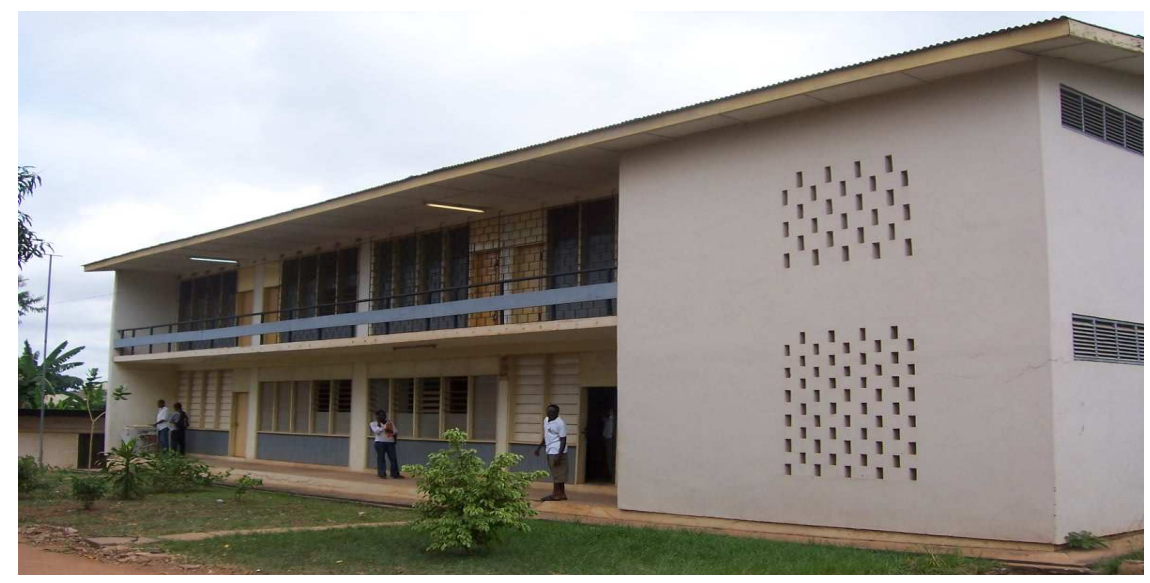

Fig. 3: The Experimental 2-storey Office Block for DHPR on Kwame Nkrumah University Science and Technology (KNUST) campus built with TEK-Block in 1975 (Authors' Field Survey, 2008). 
Evaluation of stabilized-earth (TEK) block... 110

Again, Ankaase, a village off the Kumasi Mampong road, the north- western part of $\mathrm{Ku}-$ masi, has one of its neighbourhoods built with TEK-Block by individuals who have had contact with the DHPR. Comparatively, two of the buildings are in fairly good (e.g. Fig. 4) and one poor (Fig. 5) conditions due to neglect and abandonment.

Nkenkaasu is a town with population of about five thousand population in the Offinso-North District in the Ashanti Region. Driving North,

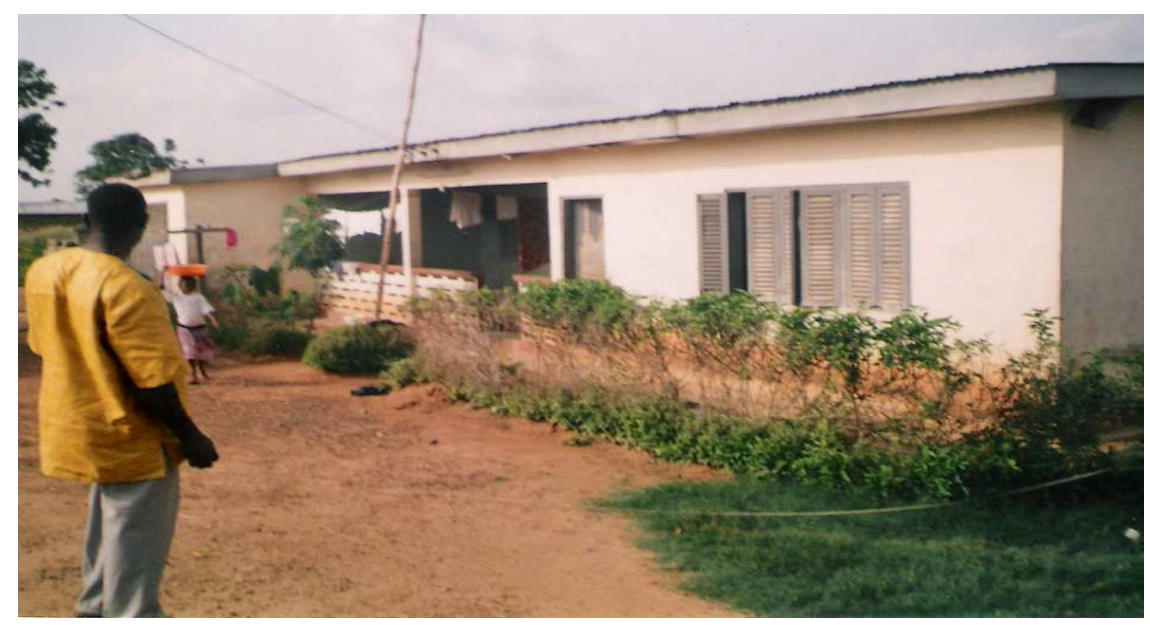

Fig. 4: One of the buildings in TEK-Blocks in good conditions at Ankaase (Authors' Field Survey, 2008).

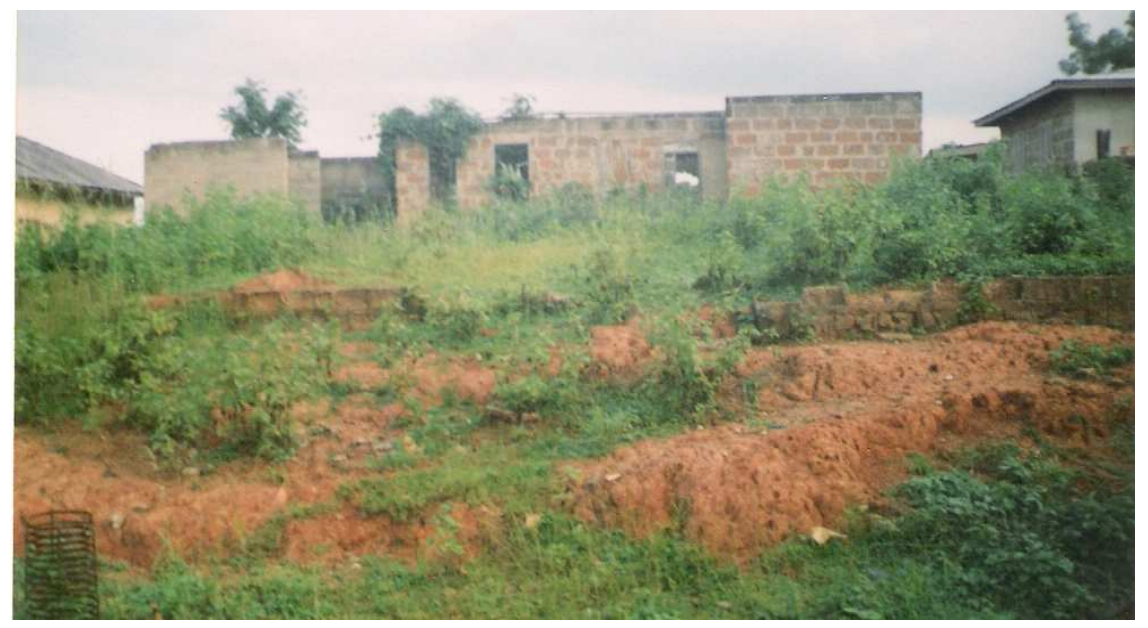

Fig. 5: Ruined building in TEK-Blocks left at the mercy of the weather due to lack of funding at Ankaase (Authors' Field Survey, 2008) 


\section{Oppong and Badu}

Nkenkaasu is about 90 kilometers from $\mathrm{Ku}$ masi. Two main types of buildings constructed with TEK-Blocks were identified at Nkenkaasu. The first one was a five-bedroom "self-contained" fully completed in TEKBlocks. Oral history indicated that, the building was designed, and its construction undertaken by the DHPR for a Tema-based native of the town; who perhaps was inspired by the TEKBlocks housing project in Tema. The second was a group of ten houses built by Habitat for Humanity International, a non-profit ecumenical Christian Housing Ministry for the poor and homeless in the town. The study found that the use of the TEK-Block was discontinued for sand-cement blocks, because the prospective homeowners found the TEK-Press machine for the manufacturing of the TEK blocks very cumbersome to use.

\section{Bunso}

Bunso is a farming community in the Eastern Region of Ghana. Its agrarian nature has attracted agricultural research centres and institution into the area; Typical among them are the Bunso Cocoa College and Crop Research Institute (CRI). The Bunso Cocoa College established in 1950 had all the buildings in stabilised earth blocks as well as some recent ones, such as the workshop building and some staff accommodation as well as office accommodation in TEK-Blocks. Owing to good maintenance practices, the buildings appeared to be in good conditions (Figure 6) because the buildings have "good hat" [roof structure with wide overhangs] and "good shoes" [foundation of concrete aprons] (Hadjri, 2007).

According to the Principal of CRI, "The rooms' ambient environmental conditions are just perfect and cannot be compared." The Principal of CRI personally requested to put on record that "Ghana in terms of building materials is sitting on gold but yet poverty stricken due to over reliance on imported building materials."

\section{Tema-Co-operative Housing}

Tema is located on the North-Eastern part of
Accra in the Greater Accra Region. The Tema Co-operative Housing was part of the Housing policy of the One-Year Development Plan of the Busia Government (1969-1972). The Cooperative Housing in Community 8 was started in 1970 and over hundred houses were built between 1970 and 1976 in two phases (Fig. 7). The scheme was initiated to help low-income workers to own houses through a hire-purchase system. Even though some of the buildings have been transformed from TEK blocks into sand-cement buildings, a sizable number remain in TEK - Blocks at the time of data collection. The owners intimated that 'they too would transform when they become economically sound.'

\section{FINDINGS AND DISCUSSIONS}

The main themes of discussion were: acceptance, durability/performance, popularity, affordability levels and design and construction as well as maintenance issues of the material. The perceptions of the participants enabled an easy triangulation of the views expressed in the semi-structured questionnaire survey of thirtytwo respondents. Responses from the semistructured survey were analysed using the Statistical Package for Social Sciences 18 (SPSS18) to generate simple frequencies. The questionnaire administration was insitu and the ethno-narratology approach enabled a hundred percent response rate to the questionnaires. However, not all the questions were answered especially those related to incomes and expenditures as well as some political issues. The research ethical considerations were observed. With the participant-observation technique, physical features and activities of the family members within the house provided inkling about the economic status of the residents and respondents. As time went by, the authors became more involved in the study areas (communities) and residents willingly extended invitation to authors to view dampness in their bathroom walls and other physical deteriorations of the TEK block houses. 


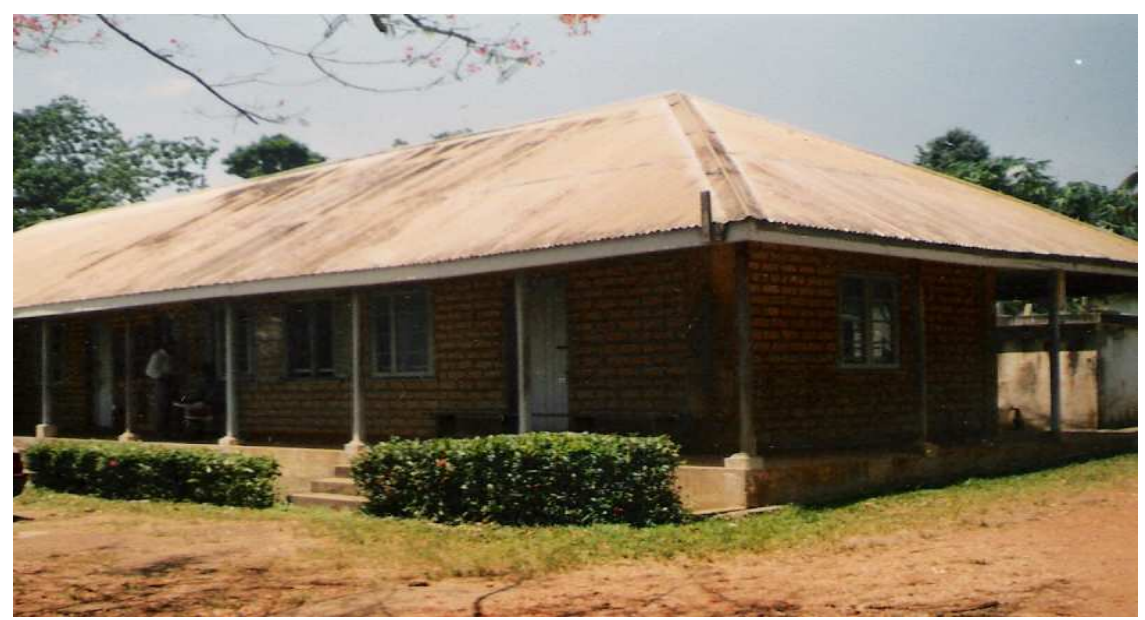

Fig. 6: Office accommodations in TEK-Blocks at Bunso in a well landscaped environment (Authors' Field Survey, 2008)

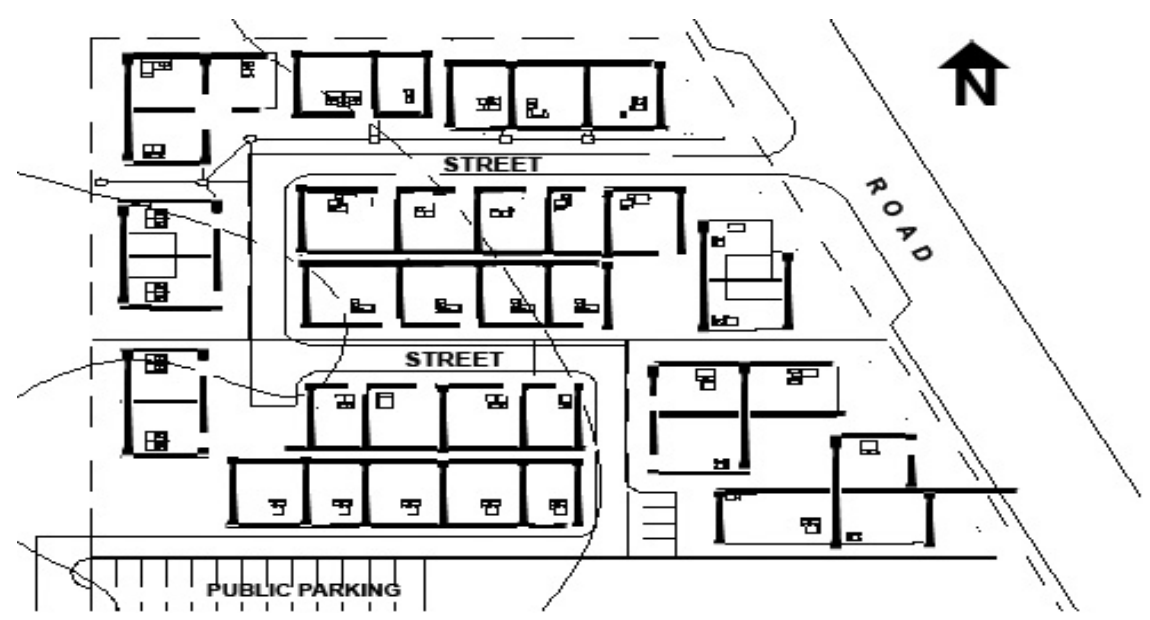

Fig. 7: Layout of a portion of residential estate built of TEK Block houses in Community 8, Tema in the Greater Accra Region (Authors' Field Survey, 2008).

Building with TEK Blocks: acceptance and durability

TEK block appeared not to have found the acceptance it deserves especially in the urban Ghana environment, largely due to durability and aesthetic issues. Afrane and Asamoah
(2011) asserted that house building Kumasi, for example, is mostly dependent on imported materials and components; the most common wall fabric is sandcrete blocks. About $90 \%$ of the respondents during the focus group discussions in Tema acknowledged that their TEK block 


\section{Oppong and Badu}

buildings have been used as residential homes since the 1970 and the main problem has had to do with durability. The urban users of the material perceived it as suitable for rural dwelling houses. The problems identified were mainly:

- excessive water absorption, causing; cracks and deterioration by frequent wetting and drying (swelling and shrinkage), weakening and disintegration by rain and floods;

- low resistance to abrasion and impact, thus rapid deterioration through climatic elements and human usage, and penetration by rodents and insects;

- low tensile strength, making earth constructions susceptible to destruction.

\section{Design and construction}

A well-designed building with well-compacted TEK block walls with wide roof overhangs can do without external rendering, though in humid climates some surface protection is usually recommended (Kabiraj and Mondal, 2011); not just for the poor but rich as well (Zami and Lee, 2011). Good quality compressed TEK blocks generally need no surface protection, thus saving cost, time and energy. If a render/plaster is applied, the choice is very wide, and some experience is needed to select the most appropriate one.

The Principal of CRI corroborated the forgoing when he said:

"...our buildings here have never been painted because the bricks require no paint. It did not cost much to build because we did not plaster them. The roofs are wide enough to protect the walls and the concrete aprons protect the foundations from being washed away".

The study revealed that $80 \%$ of the TEK-Block houses were designed by Architects and 3\% by Masons and Draughtsmen between 1950 and 1992. Thirty-one percent of the buildings were built in the 1970s - a period where the use of local building materials attracted the attention of governments in most developing and third world countries. $77 \%$ of the sampled housing units were designed by Architects from DHPR, followed by $14 \%$ by Civil Engineer and about $3 \%$ by building technicians.

\section{User preference and material acquisition}

The survey revealed that about $28.6 \%$ of respondents preferred sandcrete block due to its durability and prestige as against $8.6 \%$ for the TEK-Block, because it is affordable but not durable and less prestigious. Again, about $34.3 \%$ of the sampled views preferred the technology of the stabilised earth blocks in the rural areas as against $28.6 \%$ who thought, since Ghana is endowed with laterite and the technology could be preferred and applied everywhere in the country. Contrary to the availability nature of the laterite, about $57.1 \%$ purchased laterite as against $17.1 \%$ who obtained the laterite from the buildings site. Perhaps, one of the most striking areas of consensus was the value people placed on earth based building materials. Across all age groups, sand-cement based (sandcrete) building material was regarded as modern and more preferred. Whilst that finding could be interpreted as illustration of preference of building materials in Ghana, it invariably points to a complex interpretation.

One respondent however maintained that:

"Even though, we have to use our local building materials, the soil we need for the TEK blocks is very expensive and also not available to buy. The sandcrete blocks are still cheaper and affordable and it makes construction faster...the sandcrete block is a modern building material but the TEK blocks are not and I doubt if they can last like the sandcrete ones we have".

Another observed:

“...to be frank, I don't think we can use these TEK blocks to build beautiful houses in the city. Whether you like it or not people will not accept it like the cement blocks. I am not convinced about that...even government does not use them. If TEK block is good, why shouldn't government use it in government projects going on in the country"? 
Evaluation of stabilized-earth (TEK) block... 114

The study showed that the TEK-Block was not known to many Ghanaians, especially the youth. Thirty-one percent of the sampled views were completely not knowledgeable about the TEK-Block with the main reason being that, there is no publicity of the TEK block as housing construction material. When asked who should be responsible for the acceptability of TEK blocks as credible alternative to sandcement blocks, majority of the respondents $(48 \%)$ thought the greatest responsibility for acceptability lies with government (Table 2).

Whilst that is qualitatively reinforced, there was the recognition amongst respondents that issues of acceptability is a complex one and requires great political will from government and those involved in the building construction industry, to surmount the problems of TEKBlocks and other local building material to alleviate homelessness. The respondents wanted 'leading by example' from government and building industry professionals. One respondent concluded:

"A journey of thousand miles begins with a step and Ghana has come a long way by developing the basic technologies in the application of local materials for house construction...the people in politics have to do more for local industries in Ghana."

\section{Making of TEK Blocks}

Most of the buildings, about $69 \%$ in the study areas had their TEK-Blocks manufactured by the DHPR. Most users found the manufacturing process of the blocks laborious and cumbersome. All the respondents, when asked, preferred a modified hand-operated TEK-Block machine to reduce the number of persons used in its operation. John Dye of DHPR reported in a Research Bulletin in 1974 that, three years after the introduction of the hand-operated TEK block machine, Tek-Power Block was designed and developed to produce stabilised-earth blocks more quickly and cheaply but there were serious doubts about the adequacy and cost effectiveness of the machine and that killed the enthusiasm to improve upon the TEK block machine (Dye, 1974). About $96 \%$ of individuals who had operated the TEK block machine had no training on how to operate the machine

\section{Table 2: Respondents' perception of responsibility towards the acceptability of TEK Blocks} in Ghana

Of the following, who do you think has the greatest responsibility towards the acceptability of TEK blocks as credible alternative building material in Ghana? By respondents $(N=39$, aged $18+)$ from semi-structured survey questionnaire.

\begin{tabular}{lc} 
Construct & \% \\
\hline Architects & 9 \\
Local communities & 8 \\
Government & 48 \\
Real estate developers & 4 \\
Other building professionals aside architects & 2 \\
Individual building developers & 11 \\
Business people & 7 \\
Others & 2 \\
No idea & 9 \\
Total & $\mathbf{1 0 0}$ \\
\hline
\end{tabular}

Source: Authors' Field Survey, 2008 


\section{Oppong and Badu}

and this contributed to early breakdowns.

At Nkenkaasu, the Baanuse Project sponsored by Habitat for Humanity reverted to the use of an improvised form of the manual sandcrete block moulding machine which lacked compaction and compressive mechanism for the required stabilisation because the users preferred the improvised machine due to its simplicity. On the question of stabilisation, cement was found to be the most widely used stabiliser. Forty-seven percent of the sampled views added cement as stabilisers, even though the cost of cement keeps soaring. This paper noted that though the cost of cement keeps increasing, the procurement of cement as an additive to laterite to produce TEK blocks is not as difficult today as Dinye and King (1984) encountered on the feasibility study of Foase housing cooperative project in the Ashanti region through the technical assistance of the Housing and Planning Research Department, U.S.T., Kumasi.

\section{Cost of TEK-Block}

Detailed cost analysis and durability of TEKBlock as a building material were not the focus of the research but this paper endeavours to present some ideas of costing by comparing TEK-Blocks with sand-cement (sandcrete) blocks which are commonly used for building construction in Ghana (Afrane and Asamoah, 2011). The elements of cost in producing TEKBlocks like any other building material consist of material cost, labour and cost of machinery. Cost data on TEK-Block is not readily avail- able because it is not commonly used as compared to the sandcrete blocks. The research respondents could not tell how much a piece of TEK-Block cost at the time they were building since they did not make any systematic attempts to keep records during construction of their dwellings. Nevertheless, figures obtained from the Centre for Settlement Studies Workshop in the College of Architecture and Planning, KNUST are presented in Table 3. A cursory analysis indicated that more TEK-blocks would be needed in a building construction and since most users found the manufacturing process of the blocks laborious and cumbersome, the sandcrete block will continue to dominate the TEK-block unless a technology is developed to bring it at par with sandcrete blocks in terms of size.

\section{Maintenance}

Though maintenance is done in some study areas, unplanned maintenance was found to be popular due to the fact that the Maintenance Manuals were not provided for the houses designed and constructed in TEK-Blocks. However, through the Delphi technique, it was revealed that, the Department of Housing and Planning Research developed general requirements for building design and construction in stabilised-earth blocks but they were not followed by users (Abloh et al., 1974).

\section{CONCLUSION AND RECOMMENDA- TION}

TEK block is about four-decades old in Ghana. Yet, the paper has revealed that the TEK-block

Table 3: Cost of TEK-Block in comparison with Sancrete block in Ghana

\begin{tabular}{|c|c|c|c|c|}
\hline \multirow{3}{*}{ Type of Block } & \multicolumn{3}{|c|}{ Cost $($ Ghe $)$ per Block } & \multirow{3}{*}{$\begin{array}{l}\text { Block } \\
\text { size / dimension } \\
\text { (in } x \text { in } x \text { in) }\end{array}$} \\
\hline & & & & \\
\hline & 2010 & 2011 & 2012 & \\
\hline TEK-Block & 0.40 & 0.60 & 0.70 & $6^{\prime \prime} \times 7^{\prime \prime} \times 12^{\prime \prime}$ \\
\hline Sand-Cement (Sandcrete) & 0.90 & 1.0 & 1.20 & $6^{\prime \prime} \times 5^{\prime \prime} \times 18^{\prime \prime}$ \\
\hline
\end{tabular}

(Source: Centre for Settlement Studies Workshop-KNUST, 2012) 
Evaluation of stabilized-earth (TEK) block... 116

block as a product appears not to have made any impact. The reasons for this seem to be lack of: strength, durability, popularity and asocial perception of acceptability. Ninety percent of the respondents during the focus group discussions in Tema acknowledged that their TEK block buildings have been useful as residential homes for forty years even though they cited, for example, excessive water absorption, cracks and deterioration by frequent wetting and drying, low tensile strength as major problems confronting TEK block as a building material. However, this paper has revealed that TEK block buildings at the Bunso Cocoa College and KNUST have withstood the vagaries of the weather due to appropriate design parameters such as wide overhangs, extensive plinth areas and high pitched roof forms. And that, it is appropriate for government and the building industry in Ghana to use TEK block buildings at the Bunso Cocoa College and KNUST as better examples to inform practitioners in the housing and construction sectors and individual Ghanaian about the integrity of TEK block as credible building material in Ghana.

Again, the general view of respondents is that, TEK-Block machine needs modification and this paper calls on the KNUST to re-visit the "Tek-Power Block" designed and developed by John Dye as improvement over TEK-Block press to produce stabilised-earth blocks more quickly and cheaply. Notably, local building materials are not only constrained by market distortions in favour of imported 'conventional' materials but also suffer lack of appropriate design and policy direction to balance supply with demand.

Therefore, this paper suggests as a local policy direction, conscious attempts by government to introduce and publicly debate the use of local building material in government oriented projects in Ghana. That is how public awareness could be enhanced about local building materials for housing provision and acquisition as well as jobs creation for economic prosperity as
Ghana seeks a middle income economic status by 2020 .

\section{ACKNOWLEDGEMENTS}

The authors are grateful to the Department of Housing and Planning Research (DHPR) now Centre for Settlements Studies (CSS) of KNUST for providing the initial funding for the study. The authors are indebted to Mr. Sammy Ballace, a former administrator of DHPR, who provided direction and support to search through Departmental closed files and archives for the locational identification of TEK block buildings in Ghana. The authors are also grateful to the technical section of DHPR for retracing layout of plans for the purposes of this research. Finally, authors are grateful to the anonymous reviewer(s) for the review comments and suggestions have greatly enhanced the academic rigour of this paper.

\section{REFERENCES}

Abloh, F. A., Tamakloe, E. K. A. and Okie, J. S. (1974). Nsutam Report: A Resettlement Study, Department of Housing and Planning Research, Faculty of Architecture, UST Kumasi, p.22.

Afrane, S. K. and Asamoah, P. K. B. (2011). "Housing Situation in Kumasi" in: Future of the Tree - Towards growth and development of Kumasi, Kwasi Kwafo Adarkwa (ed), University Printing Press, KNUST, Kumasi, p.87

Amanoo, V. (1978). "Investigation into the load bearing Potential of landcrete Blocks for Hostel building of not less than 3 - Storey." unpublished undergraduate dissertation, Faculty of Architecture, U.S.T., Kumasi

Andersen, J. E., Andreasen, J. and Tipple, G. (2006). "The demise of compound house: consequences for the low income population of Kumasi, Ghana." RICS Research Paper $6: 8$, p.5.

Badu, E. and Owusu-Manu, D. (2011). “Over- 


\section{Oppong and Badu}

view of Construction Activities in Kumasi" in: Future of the Tree - Towards growth and development of Kumasi, Kwasi Kwafo Adarkwa (ed), University Printing Press, KNUST, Kumasi, pp. 270-289.

Bourgeois, J. L. (1987). "The History of the Great Mosques of Djenné." African Arts, 20 (3):54-63.

Davies, S., Romano, P. S., Schmidt, E. M., Schultz, E., Geppert, J. J. and McDonald, K. M. (2011). "Assessment of a Novel Hybrid Delphi and Nominal Groups Technique to Evaluate Quality Indicators." HSR: Health Services Research, 46 (6-1):2005-2011.

Department of Housing and Planning Research [DHPR], (1971). Tema Pilot Housing Scheme - Proposal for a Pilot Housing Cooperative in Community 8, Faculty of Environmental and Development Studies, UST, Kumasi.

Dinye, R. D. and King, R. S. (1984). Feasibility Study of Foase Housing Co-Operative Scheme, Department of Housing and Planning Research, Faculty of Architecture, University of Science and Technology, Kumasi, pp. $25,36,41$.

Dunn, C. S. and Obi, B. C. A. (1969). "Some Engineering Properties of Cement Stabilized Kenper Marl with particular reference to Rapid and Repeated Compressive Tests." Journal of Engineering Geology, 2 (1):12548.

Dye, J. (1974). “Tek-Power Block Progress Report." Research Bulletin, Vol.1, No. 3, Department of Housing and Planning Research, Faculty of Architecture, University of Science and Technology, Kumasi, pp.34-38.

Gbeckor-Kove, A. A. K. (1988). Improved and Simplified Earthen Building Construction, Department of Housing and Planning Research, Faculty of Architecture, University of Science and Technology, Kumasi, pp.-iii, $1-12$.

Gooding, D. E. and Thomas, T. H. (1995). "The Potential of Cement-Stabilised Building Blocks as an Urban Building Material in Developing Countries." DTU Working Paper No.44 December, 1995, pp.4-7.

Groat, L. and Wang, D. (2002). Architectural Research Methods, John Wiley \& Sons Inc., New York/Canada, pp.182-3.

Hadjri, K. (2010). “An Assessment of Sheltered Housing Design in Belfast, Northern Ireland," Journal of Housing for the Elderly, 24 (2): 177-180.

Hadjri, K., Osmani, M., Baiche, B. and Chifunda, C. (2007). "Attitudes towards earth building viability for Zambian housing provision." Engineering Sustainability, 160(ES3): 141-142.

Jalali, S. and Pimenta, C. E. (1999). "Durable Cement Stabilised Pressed Earth Blocks by incorporation of Rendering." British Masonry Society, Masonry International, 12 (3):85-88.

Kabiraj, K. and Mondal, U. K. (2011). "Affordable Housing: Stabilised compacted earth block for affordable housing." Indian Concrete Journal, 85(8):52-60.

Kostof, S. (1995). A History of Architecture Settings and Rituals, Oxford University Press, pp.46, 50.

Kronenburg, R. (2001). Spirit of the Machine: technology as an inspiration in architecturaldesign, Wiley-Academy, Great Britain, p.62.

Ngowi, A. B. (1997). "Improving the traditional earth construction: a case study of Botswana." Construction and Building Materials, 11(1):1-7. 
Evaluation of stabilized-earth (TEK) block... 118

Nworie, J. (2011). "Using the Delphi Technique in Educational Technology Research." TechTrends, September/October 201, 55 (5):24-25.

Ofori, G. (1985). "Indigenous construction materials programmes: Lessons from Ghana's experience." Habitat International, 9(1):7179 [available online on 16 July 2002, accessed online on 3 April, 2011].

Okie, J. S. (1971). "Block Press Handbook for making soil blocks with a TEK-Block Press." Department of Housing and Planning Research, Faculty of Environmental and Development Studies, KNUST, Kumasi.

Osei-Asibey, D. (1987). "Rationalization of Sun-Dried Mud Block Construction." Unpublished undergraduate dissertation, Faculty of Architecture, U.S.T., Kumasi.

Owusu, S. E. (2001). "Housing Supply and Demand in Kumasi." in: The Fate of the Tree: Planning and Managing the Development of Kumasi, Ghana, K.K. Adarkwa and J. Post (eds). Thela. Thesis/Woeli, Amsterdam and Accra, pp.101-121.

Seemann, N. (2011). "Constructive Dialogue Community Building as a Tool of Social Change." in: New directions in sustainable design, Adrian Parr and Michael Zaretsky (editors), Routledge Taylor and Francis Group, pp.115-128.

Sperling, R. (1962). Soil-Cement Blocks effect of soil composition on durability and other properties, West African Building Research Institute.

Wellington, H. N. A. (2011). Stones Tell Stories at Osu - Memories of a Host Commu nity of the Danish Trans-Atlantic Slave Trade, Sub-Saharan Publishers, Legon - Accra, Ghana, pp. viii-xix.

Yeboah, I. E. A. (2003). "Demographic and Housing Aspects of Structural Adjustment and Emerging Urban Form in Accra, Ghana," Africa Today, 50 (1):107-119.

Zami, M. S. and Lee, A. (2011). "Inhibitors of adopting stabilised earth construction to a d dress urban low cost housing crisis: An understanding by construction professionals." Journal of Building Appraisal, 6 (3, 4): 227240.

Zaretsky, M. (2011). "Design from Ground Up," in: New directions in sustainable design, Adrian Parr and Michael Zaretsky (editors), Routledge Taylor and Francis Group, pp.108-113. 